\title{
AKTIVITAS FISIK, PENGETAHUAN GIZI, ASUPAN ENERGI, ASUPAN SERAT DAN STATUS GIZI LEBIH PADA REMAJA
}

\author{
Maharani, Darwis, Desri Suryani \\ Politeknik Kesehatan Kementerian Kesehatan Bengkulu, Program Studi D-IVGizi, \\ Jalan Indragiri Nomor 03 Padang Harapan Bengkulu \\ Maharanidts18@gmail.com
}

\begin{abstract}
Nutrition problems in adolescents are found in many nutrients. More nutrition (overweight) is one of the epidemic problems worldwide. Objective of the study to determine the relationship of physical activity, nutritional knowledge and fiber intake with more nutritional status in adolescents in MTSN 2 Kota Bengkulu.Penelitian this is with observational research using cross sectional design. Population taken in this research is all students of class VII and VIII in MTSN 2 City of Bengkulu Year 2017. Sampling by purposive sampling technique. The results of research on average light physical activity, adequate nutritional knowledge, energy intake more than $\mathrm{AKG}$ and fiber intake less than AKG. There is a relationship between physical activity, knowledge, energy intake, fiber intake with more nutritional status in adolescent $(\mathrm{p}<0,05)$. The most dominant variables associated with more nutritional status are nutritional knowledge $(\mathrm{p}=0,000)$. The importance of adding nutritional knowledge about obesity in adolescents in order to increase physical activity and fiber intake and reduce energy intake so as to achieve good nutritional status.
\end{abstract}

Keywords : Physical Activity, Nutrition Knowledge, Energy Intake, Fiber Intake, More Nutrition

\begin{abstract}
Abstrak:Permasalahan gizi pada remaja banyak sekali ditemukan diantaranya gizi lebih. Gizi lebih(kegemukan) merupakan salah satu masalah epidemik di seluruh dunia. Tujuan Penelitian untuk mengetahui hubungan aktivitas fisik, pengetahuan gizi dan asupan serat dengan status gizi lebih pada remaja di MTSN 2 Kota Bengkulu.Penelitian ini adalah dengan penelitian observasional dengan menggunakan rancangan cross sectional. Populasi yang diambil dalam penelitian ini adalah seluruh siswa kelas VII dan VIII di MTSN 2 Kota Bengkulu Tahun 2017. Pengambilan sampel dengan teknik purposive sampling. Hasil penelitian rata-rata aktivitas fisik ringan, pengetahuan gizi cukup, asupan energi lebih dari AKG dan asupan serat kurang dari AKG. Ada hubungan antara aktivitas fisik, pengetahuan, asupan energi, asupan serat dengan status gizi lebih pada remaja $(\mathrm{p}<0,05)$. Variabel yang paling dominan berhubungan dengan status gizi lebih adalah pengetahuan gizi $(\mathrm{p}=0,000)$.Pentingnya melakukan penambahan pengetahuan gizi tentang obesitas pada remaja agar dapat meningkatkan aktivitas fisik dan asupan serat serta mengurangi asupan energinya sehingga mencapai status gizi yang baik.
\end{abstract}

Kata Kunci : Aktivitas Fisik, Pengetahuan Gizi, Asupan Energi, Asupan Serat, Gizi Lebih

Permasalahan gizi pada remaja banyak sekali ditemukan diantaranya kegemukan (obesitas), kurang energi (kurang gizi), anemia gizi (kekurangan zat besi) dan kurang zat mikronutrien lain (Mitayani dan Sartika, 2010). Masalah gizi remaja perlu mendapatkan perhatian khusus karena pengaruhnya yang besar terhadap pertumbuhan dan perkembangan tubuh serta dampaknya pada masalah gizi saat dewasa (Pujiati, 2015).

Obesitas merupakan salah satu masalah gizi sebagai akibat dari konsumsi makanan yang jauh melebihi dari kebutuhan (Soetjiningsih dan Ranuh, 2013). Gaya hidup sedenter dan asupan yang berlebih serta tidak seimbang sering 
kali terdapat pada remaja yang mengalami kegemukan (Calvin dkk, 2013).

Remaja yang mengalami kegemukan biasanya akan terus menerus bertambah gemuk. Kegemukan yang terjadi beresiko menimbulkan masalah kesehatan, seperti penyakit jantung, diabetes melitus tipe 2, kanker, dll (Calvin dkk, 2013).

Penentuan kebutuhan zat gizi remaja secara umum didasarkan pada angka kecukupan gizi yang dianjurkan untuk Indonesia (Sulistyoningsih, 2011). Penurunan aktivitas fisik akan berakibat menurunnya pengeluaran energi dan peningkatan asupan dengan aktivitas fisik yang rendah, keduanya berpotensi menyebabkan terjadinya obesitas (Pramono dan Sulchan, 2014).

Kurang cukupnya pengetahuan tentang gizi dan kesalahan dalam memilih makanan akan berpengaruh terhadap status gizi, salah satunya kegemukan (Kristianti $\mathrm{dkk}, 2009)$. Pengetahuan tentang gizi yang rendah akan terlihat dari Perilaku makan yang salah. Perilaku makan merupakan suatu respon kebiasaan yang berhubungan dengan makanan yang dikonsumsi mencakup jenis makanan, jumlah dan waktu makan (Pujiati dkk, 2015).

Riskesdas (2013) secara nasional menunjukkan bahwa masalah status gizi remaja dilihat dari indikator IMT/U menunjukkan prevalensi gizi lebih untuk usia 13-15 tahun yaitu 10,8\% (Kemenkes RI, 2013). Berdasarkan Hasil survei awal yang didapat dari MTSN 2 Kota Bengkulu terhadap 11 siswa-siswi MTSN 2 Kota Bengkulu didapatkan 45,4\% gizi lebih.

\section{BAHAN DAN CARA KERJA}

Jenis penelitian yang digunakan dalam penelitian ini adalah dengan penelitian observasional dengan menggunakan rancangan cross sectional.Penelitian ini menggunakan 2 variabel, yaitu variabel independen dan variabel dependen.

Variabel status gizi dengan cara penimbangan dan pengkuran dengan menggunakan timbangan injak dan mikrotois hasil ukur SD dengan skala rasio. Aktivitas fisik dengan pengisian angket menggunakan form record 3x 24 jam hasil ukur PAL dengan skala rasio. Pengetahuan gizi dengan pengisian angket menggunakan kuesioner pengetahuan gizi obesitas hasil ukur dengan skala rasio. Asupan energi dengan wawancara menggunakan form food recall 3x 24 jam hasil ukur kkal dengan skala rasio. Asupan serat dengan dengan wawancara menggunakan form food recall 3x 24 jam hasil ukur gram dengan skala rasio.

Populasi yang diambil dalam penelitian ini adalah seluruh siswa kelas VII dan VIII di MTSN 2 Kota Bengkulu Tahun 2017 sebanyak 423 siswa. Pengambilan sampel siswa MTSN 2 Kota Bengkulu dilakukan dengan teknik purposive sampling, dimana sampel akan diambil berdasarkan kriteria yang telah ditentukan oleh peneliti.

\section{HASIL}

\section{Analisis Univariat}

Tabel 1. Distribusi Frekuensi Aktivitas Fisik, Pengetahuan Gizi, Asupan Energi Dan Serat Dengan Status Gizi Lebih Pada Remaja

\begin{tabular}{lcccccc}
\hline \multicolumn{1}{c}{ Variabel } & N & Mean & Median & SD & Minimum & Maksimum \\
\hline Aktivitas Fisik & 70 & 1,5669 & 1,5200 & 0,17144 & 1,40 & 2,26 \\
Pengetahuan Gizi Obesitas & 70 & 6,56 & 6 & 1,27 & 4 & 9 \\
Asupan Energi & 70 & 2553 & 2460,83 & 659,38 & 1476,5 & 4117,2 \\
Asupan Serat & 70 & 14,386 & 13,8000 & 5,69002 & 4,9 & 34,0 \\
Status Gizi Lebih & 70 & 3,5189 & 3,35 & 0,80597 & 2.10 & 5.70 \\
\hline
\end{tabular}


Rata-rata aktivitas fisik dikategorikan ringan, yaitu 1,523 PAL. Rata-rata pengetahuan gizi tentang obesitas diatas nilai tengah, yaitu 6,56. Rata-rata asupan energi lebih dari AKG, yaitu 2553 kkal.Rata-rata asupan serat kurang dari AKG, yaitu 14,386 mg. Rata-rata status gizi responden didapatkan sebesar $+3,5$ SD.

\section{Analisis Bivariat}

Tabel 2. Hubungan Aktivitas Fisik, Pengetahuan Gizi, Asupan Energi Dan Asupan Serat Dengan Status Gizi Lebih Pada Remaja

\begin{tabular}{lcc}
\hline \multicolumn{1}{c}{ Variabel } & Nilai $\mathrm{r}$ & Nilai $\mathrm{p}$ \\
\hline $\begin{array}{l}\text { Aktivitas fisik dan status gizi } \\
\text { lebih }\end{array}$ & $-0,308$ & 0,009 \\
$\begin{array}{l}\text { Pengetahuan gizi dan status } \\
\text { gizi lebih }\end{array}$ & $-0,564$ & 0,000 \\
$\begin{array}{l}\text { Asupan energi dan status gizi } \\
\text { lebih }\end{array}$ & 0,310 & 0,009 \\
$\begin{array}{l}\text { Asupan serat dan status gizi } \\
\text { lebih }\end{array}$ & $-0,299$ & 0,012 \\
\hline
\end{tabular}

Aktivitas fisik dengan status gizi didapat nilai $\mathrm{p}=0,009$ dengan nilai $\mathrm{r}=-$ 0,308 ; pengetahuan gizi obesitas dengan status gizi lebih didapat nilai $\mathrm{p}=0,000$ dengan nilai $r=-0,564$; asupan energi dengan status gizi lebih didapat nilai $\mathrm{p}=0,009$ dengan nilai $\mathrm{r}=0,310$; asupan serat dengan status gizi lebih didapat nilai $p=0,012$ dengan nilai $r=-0,299$.

\section{Analisis Multivariat}

Tabel 3. Hasil Analisis Regresi Linier Ganda Aktivitas Fisik, Pengetahuan Gizi, Asupan Energi Dan Asupan Serat Dengan Status Gizi Lebih Pada Remaja

\begin{tabular}{|c|c|c|}
\hline Model & Variabel & Nilai $p$ \\
\hline \multirow[t]{5}{*}{1} & Aktivitas fisik & $0,313^{*}$ \\
\hline & b. Pengetahuan & 0,000 \\
\hline & obesitas & 0,017 \\
\hline & c. Asupan energi & 0,043 \\
\hline & d. Asupan serat & \\
\hline \multirow[t]{3}{*}{2} & a. Pengetahuan gizi & 0,000 \\
\hline & b. Asupan energi & 0,010 \\
\hline & c. Asupan serat & 0,026 \\
\hline
\end{tabular}

Variabel aktivitas fisik memiliki $p>0,05$ sehingga variabel tersebut harus keluar dari model pertama. Selanjutnya yang mempunyai p-value terbesar ketiga, yaitu asupan serat. kemudian p-value terbesar kedua adalah asupan energi. Hasil akhir dari analisis multivariat dengan menggunakan regresi linier ganda menunjukkan bahwa variabel yang paling berhubungan dengan status gizi lebih adalah pengetahuan gizi dengan nilai $\mathrm{p}<0,05(\mathrm{p}=0,000)$.

\section{PEMBAHASAN}

\section{Hubungan Aktivitas Fisik Dengan StatusGizi Lebih Pada Remaja}

Hasil uji statistik menunjukkan bahwa ada hubungan antara aktivitas fisik dengan status gizi lebih pada remaja dengan nilai $\mathrm{p}=0,009$ dan hubungannya lemah $(\mathrm{r}=-0,308)$ serta berpola negatif yang artinya semakin tinggi aktivitas fisik maka semakin rendah status gizi. Dapat diketahui bahwa rata-rata aktivitas fisik pada remaja di MTSN 2 Kota Bengkulu dikategorikan rendah, yaitu 1,52 PAL. Hal ini sejalan dengan penelitian Pramono dan Sulchan (2014) bahwa ada hubungan antara aktivitas fisik dengan kejadian obesitas pada remaja di Kota Semarang. Hal ini didukung pula oleh hasil penelitian Wijayahadi (2010) di mana faktor dominan dari masyarakat yang menjadi penyebab gizi lebih adalah kurangnya aktivitas gerak yang meliputi aktivitas olahraga dan aktivitas pekerjaan.

Aktivitas fisik yang rendah dilihat berdasarkan hasil pengisian Angket form record sehingga dapat diketahui rata-rata aktivitas fisik remaja di MTSN 2 rendah. Beberapa contoh aktivitas fisik yang seringkali dilakukan oleh remaja gizi lebih adalah menonton tv, bermain handphone, nongkrong, tiduran, internetan dan duduk di kantin.

Aktivitas fisik meliputi kegiatan yang dilakukan baik di kantor, sekolah, tugas rumah, hobi serta olahraga. Aktivitas 
fisik merupakan salah satu pemicu terjadinya gizi lebih akibat dari rendahnya pengeluaran energi. Energi yang dikeluarkan untuk aktivitas fisik merupakan determinan utama pengeluaran energi. Penurunan aktivitas fisik akan berakibat menurunnya pengeluaran energi, sehingga memicu peningkatan simpanan lemak tubuh dalam bentuk trigliserida di dalam jaringan adiposa. Peningkatan asupan maupun penurunan pengeluaran energi berpotensi terjadinya gizi lebih (Pramono dan Sulchan, 2014).

\section{Hubungan Pengetahuan Gizi Tentang Obesitas Dengan Status Gizi Lebih Pada Remaja}

Hasil uji statistik menunjukkan bahwa ada hubungan antara pengetahuan gizi tentang obesitas dengan status gizi lebih pada remaja dengan nilai $\mathrm{p}=0,000$ dan hubungannya lemah $(r=-0,564)$ serta berpola negatif yang artinya semakin rendah pengetahuan gizi tentang obesitas maka semakin tinggi status gizi. Dapat diketahui bahwa rata-rata pengetahuan gizi tentang obesitas pada remaja di MTSN 2 Kota Bengkulu dikategorikan sedang, yaitu 6,557. Hal ini sejalan dengan penelitian yang dilakukan oleh Handono (2010) bahwa ada hubungan antara pengetahuan gizi dengan status gizi balita.

Umumnya remaja memiliki pemahaman yang baik terhadap kandungan gizi yang terdapat pada makanan dan manfaatnya bagi tubuh. Mereka yang memiliki pengetahuan tentang gizi bukan berarti akan mengubah kebiasaan makannya. Mereka mungkin mengerti tentang energi, protein, lemak, karbohidrat dan zat gizi lainnya yang diperlukan bagi tubuh tetapi mereka tidak pernah mengaplikasikannya dalam kehidupan sehari-hari. Menurut Soerjodibroto (2004) mereka pada umumnya lebih memilih makanan yang terasa enak dan mengenyangkan tetapi rendah kandungan gizinya dan tidak mengerti pentingnya makanan untuk kesehatan.

\section{Hubungan Asupan Energi Dengan Status Gizi Lebih Pada Remaja}

Hasil uji statistik menunjukkan bahwa ada hubungan antara asupan energi dengan statius gizi lebih pada remaja dengan nilai $\mathrm{p}=0,009$ dan hubungannya sedang $(r=0,310)$ serta berpola positif yang artinya semakin tinggi asupan energi maka semakin tinggi status gizi. Dapat diketahui bahwa rata-rata asupan energi pada remaja di MTSN 2 Kota Bengkulu dikategorikan lebih dari AKG, yaitu 2553 kkal. Hal ini sejalan dengan hasil penelitian Palallo, dkk (2015) bahwa ada hubungan antara asupan energi dengan status gizi pada wanita usia subur.

Asupan energi yang tinggi dilihat berdasarkan hasil wawancara menggunakan food recall sehingga dapat diketahui bahwa asupan energi lebih dikarenakan responden sering mengkonsumsi makanan yang banyak mengandung minyak dan lemak, porsi makan yang besar serta frekuensi makan yang sering. Kebutuhan energi pada usia remaja sebaiknya terpenuhi karena sedang mengalami proses pertumbuhan dan perkembangan yang sangat pesat sehingga dapat mempengaruhi perubahan bentuk dan susunan jaringan tubuh. Kebutuhan energi remaja juga perlu diperhatikan kecukupannya. Jika makanan yang dikonsumsi seringkali melebihi kecukupan yang telah dianjurkan maka dapat mengalami terjadinya gizi lebih yang akan berdampak bagi kesehatan. Beberapa penyakit yang dapat dipicu oleh gizi lebih adalah penyakit degenaratif, seperti diabetes melitus; hipertensi; penyakit jantung koroner; kanker dan lain-lain (Safitri, 2011).

\section{Hubungan Asupan Serat Dengan Status Gizi Lebih Pada Remaja}

Hasil uji statistik menunjukkan bahwa ada hubungan antara asupan serat 
dengan status gizi lebih pada remaja dengan nilai $\mathrm{p}=0,012$ dan hubungannya lemah $(r=-0,299)$ serta berpola negatif yang artinya semakin rendah asupan serat maka semakin tinggi status gizi. Dapat diketahui bahwa rata-rata asupan serat pada remaja di MTSN 2 Kota Bengkulu dikategorikan kurang dari AKG, yaitu 14,384 mg.

Asupan serat yang rendah dilihat berdasarkan hasil wawancara menggunakan food recall sehingga dapat diketahui bahwa asupan serat kurang dikarenakan responden jarang sekali mengkonsumsi makanan yang mengandung tinggi serat. Hal ini sejalan dengan pendapat Rahayuningtiyas (2012) bahwa pola konsumsi remaja, yaitu tinggi kalori dan rendah serat.

Dilihat bahwa kepedulian remaja dalam mengkonsumsi makanan yang mengandung tinggi serat masih sangat kurang. Menurut Makaryani (2013) alasan remaja jarang mengkonsumsi makanan yang mengandung tinggi serat karena kurang menyukai rasanya serta penggunaan sayur dan buah pada menu keluarga jarang sekali ditemukan, sehingga dapat mempengaruhi konsumsi serat pada remaja.

Salah satu faktor yang dapat mempengaruhi status gizi adalah asupan makan. Asupan makan yang mencakup angka kecukupan gizi dan jenis bahan makanan yang dikonsumsi seperti makanan yang mengandung sumber energi, protein, lemak dan serat. Mengkonsumsi makanan yang mengandung serat dapat membantu terjadinya rasa kenyang, karena serat dapat menyerap air sehingga mengembang, serat dapat memperlambat proses pencernaan sehingga pemenuhannya didalam perut menjadi lebih lama (Andhani, 2011).

Serat dapat diklasifikasikan menjadi 2 jenis, yaitu serat larut air dan tidak larut air. kedua serat ini sangat penting dalam proses pencernaan dan memiliki fungsinya masing-masing. Serat larut air memiliki kemampuan yang mudah larut didalam air. selain itu, serat larut air berperan dalam mencegah terjadinya konstipasi. Fungsi lain dari serat ini dapat menurunkan berat badan karena komposisi karbohidrat kompleksnya mengatur nafsu makan (Putra, 2013). Sedangkan serat tidak larut air tidak dapat larut dalam air dan juga dalam saluran pencernaan. Namun, serat ini memiliki peran dalam penyerapan air dan meningkatkan tekstur dan volume tinja. Sehingga makanan yang dicerna dapat dengan mudah dan cepat melewati usus besar (Khasanah, 2012).

Overweight yang terjadi pada remaja perlu mendapatkan perhatian, karena overweigth yang terjadi pada usia remaja cenderung berlanjut hingga usia dewasa bahkan lansia. Overweight dapat menyebabkan beberapa penyakit degeneratif, diantaranya kardiovaskular, diabetes melitus, arthritis, penyakit kantung empedu, beberapa jenis kanker, gangguan fungsi pernapasan dan berbagai gangguan kulit (Arisman, 2008).

\section{Analisis Multivariat Variabel Yang Paling Dominan Dengan Status Gizi Lebih}

Hasil uji analisis regresi linier ganda menunjukkan variabel pengetahuan gizi yang paling kuat hubungannya dengan status gizi dengan nilai $\mathrm{p}<0,05(\mathrm{p}=0,000)$ pada model kedua. Dari hasil pengisian kuesioner didapatkan rata-rata pengetahuan gizi tentang obesitas sedikit diatas nilai tengah, yaitu 6,557. Hal ini sejalan dengan penelitian yang dilakukan oleh Handono (2010) bahwa ada hubungan antara pengetahuan gizi dengan status gizi balita.

Tingkat pengetahuan seseorang berpengaruh terhadap sikap dan perilaku dalam pemilihan makanan yang pada akhirnya akan berpengaruh pada keadaan gizi individu yang bersangkutan (Istiono, dkk. 2009). Perilaku yang didasari pengetahuan biasanya akan lebih baik dibanding perilaku yang tidak didasari 
pengetahuan. Pengetahuan yang dimiliki sangat penting untuk terbentuknya sikap dan tindakan (Notoadmodjo, 2007).

Pengetahuan gizi ini mencakup proses kognitif yang dibutuhkan untuk menggabungkan informasi gizi dengan perilaku makan, agar struktur pengetahuan yang baik tentang gizi dan kesehatan dapat dikembangkan (Emilia, E., 2008).

Hal ini berbanding terbalik dengan penelitian Calvin, dkk (2013) bahwa tidak ada hubungan antara pengetahuan gizi dengan jumlah asupan makronutrien. Selain pengetahuan gizi, ada faktor lain yang mempengaruhi pola konsumsi individu. Faktor-faktor tersebut antara lain social cognitive theory (SCT) dan teori ekologis dimana hubungan keduanya menekankan timbale balik antara individu, lingkungan dan gaya hidup pola konsumsi seseorang.

Pada umumnya remaja memiliki pemahaman yang baik terhadap kandungan gizi yang terdapat pada makanan dan manfaatnya bagi tubuh. Mereka yang memiliki pengetahuan tentang gizi bukan berarti akan mengubah kebiasaan

\section{DAFTAR RUJUKAN}

Andhani NR dan Irianto SE. Perbedaan Asupan Serat Dan Cairan Berdasarkan Tingkat Pendidikan, Status Ekonomi, Dan Status Gizi Pada Lansia Di Provinsi Riau (RISKESDAS 2010). 2012. Nutrire Diasta Volume 5 Nomor 1. Jakarta

Arisman. 2008. Gizi Dalam Daur Kehidupan: Buku Ajar Ilmu Gizi, Ed.2. Jakarta: Penerbit Buku Kedokteran.

Calvin, K. Mulyadi., Karina, M. Pramudya., Kevin., Melissa Lenardi., Sri Sukmaniah. 2013. Hubungan Antropometri, Aktivitas Fisik, Dan Pengetahuan Gizi Dengan Asupan Energi Dan Komposisi Makronutrien Pada Remaja. Vol. 1, No. 2, Agustus 2013. http://journal.ui.ac.id/index.php/eJKI/article/vi ew/2054/2481. Diakses 3 Maret 2017

Handono, Nugroho Priyo. 2010. Hubungan tingkat pengetahuan pada nutrisi, pola makan, dan energi tingkat konsumsi dengan status gizi anak usia lima tahun di wilayah kerja makannya. Mereka mungkin mengerti tentang energi, protein, lemak, karbohidrat dan zat gizi lainnya yang diperlukan bagi tubuh tetapi mereka tidak pernah mengaplikasikannya dalam kehidupan sehari-hari. Menurut Soerjodibroto (2004) mereka pada umumnya lebih memilih makanan yang terasa enak dan mengenyangkan tetapi rendah kandungan gizinya dan tidak mengerti pentingnya makanan untuk kesehatan.

\section{KESIMPULAN}

Dapat disimpulkan bahwa rata-rata aktivitas fisik kategori rendah, yaitu 1,523; pengetahuan gizi kategori diatas rata-rata, yaitu 6,557; asupan energi diatas $\mathrm{AKG}$, yaitu 2553 kkal; asupan serat kurang dari AKG, yaitu 14,384 mg. Ada hubungan antara aktivitas fisik, pengetahuan gizi, asupan energi dan asupan serat dengan status gizi lebih pada remaja di MTSN 2 Kota Bengkulu. Pengetahuan gizi tentang obesitas variabel yang paling dominan terhadap status gizi lebih pada remaja.

puskesmas selogiri, wonogiri. Jurnal Keperawatan. Diakses 25 Februari 2017

Kementerian Kesehatan RI, 2013. Riset Kesehatan Dasar Tahun 2013. Kemenkes RI, Jakarta.

Makaryani, RY. 2013. Hubungan Konsumsi Serat Dengan Kejadian Overweight Pada Remaja Putrid SMA Bati 1 Surakarta. Fakultas Ilmu Kesehatan Universitas Muhammadiah Surakarta. Surakarta.

Mitayani., Sartika W., 2010. Ilmu Gizi. Jakarta : CV Trans Info Media.

Pramono, A dan Sulchan, M. 2014. Kontribusi Makanan Jajan dan Aktivitas Fisik Terhadap Kejadian Obesitas Pada Remaja di Kota Semarang. Jurnal Gizi Indonesia.

Rahayuningtiyas, F. Hubungan Antara Asupan Serat Dan Faktor Lainnya Dengan Status Gizi Lebih Pada Siswa SMPN 115 Jakarta Selatan Tahun 2012. Fakultas Kesehatan Masyarakat Program Studi Gizi. Depok.

Soetjiningsih., Ranuh, Gde. 2013. Tumbuh Kembang Anak. Jakarta : EGC.

Sulistyoningsih, Hariyani. 2011. Gizi Untuk Kesehatan Ibu dan Anak. Yogyakarta: Graha Ilmu 